\title{
Investment Opportunities and Share Repurchases
}

\author{
Walter I. Boudry* \\ Leonard N. Stern School of Business \\ New York University \\ Jarl G. Kallberg \\ Thunderbird School of Global Management \\ Crocker H. Liu \\ School of Hotel Administration \\ Cornell University
}

Current Version: 08 September 2009

\begin{abstract}
Previous studies of share repurchase have primarily focused on examining announcement effects and long-term operating performance in order to distinguish among the diverse possible hypotheses for repurchase. One of the most important rationales they have studied is the over-investment hypothesis: firms repurchase in order to avoid investing in negative net present value projects. While the recent empirical analyses have presented some indirect evidence in support of the over-investment hypothesis, this study examines this rationale for repurchase from a unique perspective, empirically showing that project returns have an important influence on the decision to repurchase shares. Our sample of firms consists of 125 real estate investment trusts (REITs) in order to utilize a time series of real estate capitalization rates (property ROAs) from market transactions on different property types. These cap rates proxy for a REIT's project opportunity set. Using a both Logit and Tobit models that corrects for other possible buyback rationales, we show that during periods with relatively low cap rates, REITs are more likely to both repurchase shares and repurchase larger amounts of shares than when cap rates are high.
\end{abstract}

\footnotetext{
*Corresponding author. KMEC Suite 9-190, 44 W 4th St, New York, NY 10012. email wboudry@stern.nyu.edu.
} 


\section{Introduction}

Share repurchase has been an active area of financial research for the last four decades. It has also been increasingly significant in global financial markets. For example, in 1999, for the first time in history, the dollar volume of share repurchase exceeded the total amount of dividends paid by U.S. firms. ${ }^{1}$ In addition, regulators in foreign markets have been relaxing restrictions on buybacks, leading to the rapid growth of repurchase outside the U.S. ${ }^{2}$

The majority of academic investigations into stock repurchase (these are briefly covered in the literature review in Section 2) examine the short-term and long-term impact of the repurchase. These papers typically test theoretical buyback motives by employing an event study and/or a measurement of after-repurchase performance (either operating performance or abnormal stock returns). A number of more recent studies have used Logit and Tobit analyses to assess the determinants of the repurchase decision.

One of the most cited motives for repurchase is the lack of attractive investment opportunities relative to the firm's cash position; this is usually referred to as the over-investment motive or hypothesis. While the academic studies have shed considerable light on the empirical validity of potential motives for repurchase, they have presented only indirect evidence addressing this important interaction between the firm's repurchase decision and the return on its investment opportunities. The most recent studies have generally supported the overinvestment hypothesis, but the evidence is indirect. This is due to the obvious difficulty in determining the firm's return on its possible projects. While these returns are available to firm insiders, they are not easily observable by researchers. This study more directly attacks this essential aspect of the repurchase question by estimating the firm's expected project returns in order to determine the extent to which these project returns influence the repurchase decision.

\footnotetext{
${ }^{1}$ See Julio and Ikenberry (2004).

${ }^{2}$ See Kim, Schremper, and Varaiya (2005) for a description of the changing foreign restrictions.
} 
We achieve this objective by focusing on Real Estate Investment Trusts (REITs). While this is a significant restriction and potentially limits the generality of our results it has a very powerful advantage: it allows us to use available data on capitalization rates (project ROAs) from observed market transactions on different property types to proxy for the REIT's project opportunity set. REITs were established in 1960 to allow retail investors to invest in commercial and other forms of real estate. Because they are restricted to passive real estate investment and because they are required to pass on $90 \%$ of taxable income as dividends, ${ }^{3}$ REITs are essentially tax-free investment conduits. ${ }^{4}$ The reason for using REITs is that they are among the most transparent investment vehicles, and because of the restrictions on their allowable investments, we can use a diverse database of market transactions to determine cap rates, which we then use to estimate the REIT's feasible project returns at any point in time. Another advantage of using REITs in our study is that there are relatively few hostile REIT mergers. ${ }^{5}$ This virtually eliminates the use of repurchases as an anti-takeover device. ${ }^{6}$ Finally, restricting our analysis to one industry avoids the confounding influence of varying levels of risk.

While a more precise definition is given in Section 3, informally one can think of the capitalization rate as being the property's Return on Assets. We obtain cap rates on 101,594 transactions with a total transaction value of $\$ 1.05$ trillion over the period 1995 to 2008 from the CoStar and Real Capital Analytics databases. Our empirical analysis uses these transactions to create a time series of project returns for each of the 125 REITs in our sample. We then examine the relation between repurchase activity and project returns. The over-investment hypothesis asserts that REITs will be more likely to repurchase shares when

\footnotetext{
${ }^{3}$ See Boudry (2009) for an analysis of REIT dividend payout policy. This paper essentially shows that REIT managers set dividends so as to minimize the tax burden of their investors. See also Hardin and Hill (2008).

${ }^{4}$ There is thus some difficulty in translating the typical motives for dividends versus repurchase as discussed in several studies of regular corporations; for example Grullon and Michaely (2002).

${ }^{5}$ There have been very few exceptions; see however Panovka (2007).

${ }^{6}$ See Bagwell (1991).
} 
project returns are relatively low, since this action would maximize shareholder value. Overall our data are strongly consistent with this hypothesis. A one standard deviation decrease in capitalization rates makes the REITs in our sample $6 \%$ more likely to repurchase shares. This same decrease in capitalization rates leads to an increase in the level of repurchases of 21 b.p. of total assets, or approximately one quarter of the average level of repurchases observed in the sample. Since REITs have essentially no internal capital available for financing projects, one would expect that these results would be even stronger for typical corporations, which have far less dependence on external capital markets.

The organization of the remainder of this paper is as follows: Section 2 provides a very brief overview of the academic literature most related to our objectives. Section 3 describes the data and empirical methodology. Section 4 presents the empirical results and section 5 concludes.

\section{Literature Review}

This section provides a brief review of the extensive academic literature on share repurchase, emphasizing those papers that are most relevant to the current study. A comprehensive treatment is presented in Allen and Michaely (2002).

\section{$2.1 \quad$ Survey Results}

Wansley, Lane, and Sarkar (1989) present survey data on the motives for share repurchase. ${ }^{7}$ They list six possible motives: (i) Repurchase can act as a substitute for dividend payments: firms may view both dividends and repurchase as alternative mechanisms for distributing cash to shareholders; the firm could prefer one mechanism over another because of tax,

\footnotetext{
${ }^{7}$ See also Baker, Gallagher, and Morgan (1981).
} 
signaling implications etc. ${ }^{8}$ (ii) As a method to adjust leverage: repurchase will increase the firm's leverage and potentially give insiders more control of the firm. (iii) To provide shares for reissue (e.g., for option exercise). (iv) Because of a lack of investment opportunities or an excess of available cash. (v) To signal favorable information about the firm's prospects or to signal that insiders view the shares as undervalued (thus this is termed the under-valuation hypothesis). ${ }^{9}$ (vi) To transfer wealth to selling shareholders. ${ }^{10}$ The strongest agreement from survey respondents was for (v), (ii) and (iv).

Point (iv) is the focus of this study. The idea is that as a firm matures or as market conditions change, its investment opportunities can diminish and/or its cash flows increase. Some firms, in order to maximize shareholder value, would then elect to buy back shares rather than invest in negative net present value projects. ${ }^{11}$

More recently, Brav, Graham, Harvey, and Michaely (2005) surveyed 348 financial executives with regard to their perspectives on dividends and share repurchase. Among their key findings relating to repurchase were the following: repurchase decisions are made after investment decisions are undertaken; firms are concerned with the impact of repurchase on EPS $;{ }^{12}$ firms opt to repurchase when they hold excess cash or have a lack of good investment opportunities. The last of these three points is most relevant to this paper.

A motivation not directly addressed in these early survey papers is the agency motive. A related area of particular academic interest is the interaction between repurchase and

\footnotetext{
${ }^{8}$ Guay and Harford (2000) also analyze the role that permanent versus transitory cash flow shocks play in this decision.

${ }^{9}$ Some studies, e.g., Kahle (2002), refer to the latter as the free cash flow theory.

${ }^{10} \mathrm{~A}$ number of studies also address the tax issues of repurchase versus dividends as a means of returning capital to investors; these papers date back to Bierman and West (1966) and Elton and Gruber (1967). See also Bagwell and Shoven (1989). This issue is more complex for REITs since their dividends do not qualify for the usual favorable dividend tax treatment.

${ }^{11}$ The recent $\$ 15$ billion repurchase plans announced by IBM illustrate this point. According to one source (v3.co.uk): "On the surface the decision may seem to be a positive one for shareholders, but on the flipside this essentially means that IBM has nothing better to spend the money on than trying to raise the share price by financial machinations rather than by selling more product."

${ }^{12}$ Bens, Nagar, Skinner, and Wong (2003) study the relation between repurchase and EPS. They find that managers tend to increase buybacks in order to maintain a target rate of EPS growth.
} 
executive option compensation; these issues will be discussed further below.

\subsection{Repurchase: Theoretical Background}

This section reviews some of the most relevant theoretical papers in order to frame our econometric analysis. Since repurchase and dividends can be viewed as substitutes, ${ }^{13}$ many of the theoretical arguments that address dividend policy can be applied to share repurchase as well. These include the early signaling models of Bhattacharya (1979), Vermaelen (1984), Miller and Rock (1985) and Ofer and Thakor (1987). Broadly stated, these asymmetric information models imply that dividends and share repurchase are credible signals of the firm's future prospects. Thus, the signaling hypothesis will imply that share repurchase is a signal of future over performance. A closely related theory, which has considerable support from the above survey results, is the under-valuation hypothesis. This is another version of the asymmetric information story. Managers have superior knowledge about their firm's true value and repurchase their shares when the market under values the firm.

The parallel between dividend theories and repurchase also applies to the diverse agency cost arguments. From the earliest, Jensen (1986), these papers have focused on dividends and repurchase as a solution to the over-investment problem. These payouts reduce divertible cash flow and mitigate managements' incentives to invest in negative net present value projects. As noted above, we refer to this as the over-investment hypothesis.

Finally, there are a number of papers (e.g. Kahle (2002)) that deal with the darker motives for repurchase. It is possible that insiders can use their valuable private information to time repurchase decisions to, for example, maximize the value of their performance-based compensation or to engage in profitable insider trading.

\footnotetext{
${ }^{13}$ This exchange of repurchase for dividends is in fact dubbed the substitution hypothesis; see Grullon and Michaely (2002).
} 


\subsection{Repurchases: Empirical Results}

The early empirical work focused on the market reaction to the announcement of openmarket and tender offer repurchases. The earliest papers, Dann (1981), Vermaelen (1981) and Bartov (1991) supported the signaling story. They showed that the announcement effects were strongly positive, and that long-term returns were also positive, partially because of EPS growth. This point was further refined in Nohel and Tarhan (1998), which showed that the EPS gain came from high book-to-market firms, consistent with the over-investment hypothesis. ${ }^{14}$ Dittmar (2000) and others have provided significant support for the undervaluation hypothesis.

The more recent literature favors the over-investment hypothesis over the signaling story. Ikenberry, Lakonishok, and Vermaelen (1995), Guay and Harford (2000) and Jagannathan and Stephens (2003) show a decline in earnings after the repurchase. However, Lie (2005) correcting for pre-repurchase performance, attributes much of this decrease to mean reversion. These results are generally robust when applied to non-U.S. data. See, e.g., Ikenberry, Lakonishok, and Vermaelen (2000) and Rau and Vermaelen (2002) ${ }^{15}$

A twist on the agency implications of buybacks is developed in Kahle (2002), which studies how the structure of employee stock options influences repurchase behavior, suggesting that the recent growth in repurchase activity could be a result of the great increases in executive option compensation. She further finds that the presence of executive options leads to greater buyback activity. ${ }^{16}$ Related work on the market timing ability evidenced by Hong Kong stock buybacks is found in Brockman and Chung (2001).

An important issue in open-market repurchases is the extent to which firms actually buy

\footnotetext{
${ }^{14}$ Lie (2005), using data for 1981-2000, estimated announcement effects for open-market repurchase averaging $3.0 \%$, a figure that is comparable to the initial studies.

${ }^{15}$ The latter paper suggests that the U.K.'s stricter regulatory environment dampens the adverse information effect, making short- and long-term abnormal returns lower than the figures found in comparable U.S. studies.

${ }^{16}$ See also Fenn and Liang (2001).
} 
back the stated number of shares. Recent evidence, e.g., Lie (2005), has shown that actual repurchase, rather than merely the announcement of an open market repurchase program, leads to superior operating performance after the repurchase.

\section{$2.4 \quad$ REIT Repurchases}

A recent paper that tries to disentangle the various motives for repurchase in the case of REITs is Brau and Holmes (2006). This study analyzes the cumulative abnormal returns around repurchase announcements in order to determine the extent to which the signaling hypothesis can be tested in light of the competing theories. They argue that the unique structure of REITs (in particular the restriction on paying out $95 \%$ of taxable income as dividends) makes two competing hypotheses dominate over the alternatives.

Ghosh, Harding, Sezer, and Sirmans (2008) address REIT repurchases from a different perspective. Using repurchases announcements from 1997 to 1999, they separate REITs into a group that did buybacks and another with no buybacks. They then use a Logit framework to show, consistent with Kahle (2002) and others, that option compensation increases the possibility of a buyback. Neither of these papers directly address the over-investment issue.

\section{Data and Empirical Approach}

The basic empirical approach follows Fenn and Liang (2001) and others by employing Logit and Tobit models to determine the influence of various possible repurchase motives on the decision to buy back shares. The unique aspect of our analysis is that, in addition to the typical controls used in related buyback studies, we use the cap rate as a possible explanatory variable. 


\section{$3.1 \quad$ Repurchases}

Although a common variable of interest, the actual value of shares repurchased is not a straight-forward variable to measure. The most accurate measure is the actual shares repurchased multiplied by the average price of repurchased shares that is reported in the firm's financial statements. Unfortunately detailed disclosure of repurchase activity has only been a requirement since 2004. In a hand collected sample of firms, Banyi, Dyl, and Kahle (2009) horse race various measures of shares repurchases against the measure of share repurchases made in the firms' financial statements. They show that the line item "shares repurchased" from the cash flow statement is the best proxy for this measure once it has been adjusted for preferred stock repurchases.

In order to extend our sample to before 2004, we employ a hybrid measure of share repurchases. Where available, we obtain from SNL the number of shares repurchased and the average price of repurchased shares from the firm's 10-K. When these variables are available, the dollar value of share repurchases is the product of these two variables. When these variables are not available, we use the line item common shares repurchased from the cash flow statement. ${ }^{17}$ Where no data is reported in SNL, we examine the firm's $10-\mathrm{K}$ and either verify that there were no share repurchases made during the year or reconstruct the amount of share repurchases from the information in the $10-\mathrm{K} .{ }^{18}$

Table 1 reports descriptive statistics of stock repurchases made by 125 REITs between 1996 and 2008. Repurchases are measured as the dollar value of share repurchases made during the year, divided by the market capitalization of the firm at the start of the year and are reported in percentages. Of the 125 firms in our sample, 89 repurchased stock during

\footnotetext{
${ }^{17}$ REITs typically report both common and preferred stock repurchased in the cash flow statement. SNL collects these line items separately, so no adjustment is necessary for preferred stock repurchases.

${ }^{18} \mathrm{~A}$ blank line item in SNL is caused by the absence of the line item in the firm's statement of cash flows. This can either be due to the firm not conducting any repurchase activity during the year or SNL not recording the line item because the firm aggregated common and preferred share repurchases. By examining the discussion in the $10-\mathrm{K}$ we were able to distinguish the amounts due to common and preferred share repurchases.
} 
the sample period so it does not appear that repurchases are driven by a few firms. Overall, the mean value of repurchases is $0.88 \%$ which is lower than the value reported for studies focusing on non-REITs. ${ }^{19}$ Due to their dividend payout requirement, REITs are likely to have far less free capital than regular corporations, which would explain the lower overall level of repurchases. ${ }^{20}$ Even though the average repurchase is lower, Table 1 shows that there is considerable variation in the amount repurchased by both time and firm. In fact, the maximum repurchase in any given year is quite large, suggesting that REITs do at times undertake large repurchase activity. Given that these firms are constrained by their dividend payout requirement, any results we do find are likely to be more pronounced in a sample of regular corporations that do not face this constraint.

\subsection{Investment Opportunities}

A poor investment opportunity set is a common explanation for repurchase decisions. When faced with bad investment opportunities, managers should return capital to investors rather than invest in poor projects. The difficulty the prior literature has faced is that in general the researcher cannot observe the firm's investment opportunity set. As such various proxies have been used to indirectly measure the firm's investment opportunity set. ${ }^{21}$ We overcome this problem by examining a set of firms whose assets trade in public and private markets. A REIT's main asset is a portfolio of properties. These properties trade directly in private markets as well as through public markets via trading in the REITs themselves. By obtaining pricing information from the underlying real estate markets and relating these market transactions to the REIT's portfolio, we are able to construct the investment opportunity

\footnotetext{
${ }^{19}$ See, for example, Fenn and Liang (2001).

${ }^{20}$ NAREIT reports that the average dividend yield for equity REITs over the sample period was $6.16 \%$. Aggregating this with our repurchases data gives an average total payout of $7.06 \%$ which is considerably higher than the total payout reported by Fenn and Liang (2001) of 2.5\% or Jagannathan, Stephens, and Weisbach (2000) of $3 \%$.

${ }^{21}$ See Gaver and Gaver (1993) for a discussion.
} 
set that the REIT faces at a given point in time.

The metric we use to measure the investment opportunity in the underlying real estate market is the Capitalization Rate, or cap rate. The cap rate - a property's Net Operating Income (NOI) divided by its transaction price - is a standard valuation metric in real estate. ${ }^{22}$ Since NOI is the property equivalent of Earnings Before Interest, Taxes, Depreciation and Amortization (EBITDA), by definition the cap rate is equivalent to pre-tax Return on Assets.

Although the cap rate is not the property IRR, at a theoretical level it is possible to decompose the IRR into the cap rate plus expected NOI growth using a perpetual growth model. From a practical perspective we know that real estate investors' cap rate and IRR expectations are highly correlated. An examination of cap rates and expected IRRs obtained from surveys conducted by PWC Korpacz shows that these two measures are highly correlated. For Industrial properties the correlation is $86 \%$, for Multifamily it is $97 \%$, for Office it is $92 \%$ and for Retail it is $98 \%$. So although we do not have IRRs, the measure we do have is very highly correlated with expected returns. ${ }^{23}$

We obtain transactional cap rates from CoStar and Real Capital Analytics, the two leading industry sources for such data, for the period 1995 to 2008 . In order to make the properties comparable to the underlying REIT portfolios, we place 4 filters on the transactions data. First, we limit the sample to core property types (Office, Industrial, Multifamily and Retail.) The reason for including only these four property types is simply one of practicality. Other property types, such as Hotel and Health Care, do not experience frequent enough transactions to create an accurate time series of cap rates for these property types across different locations. Also, since REITs tend to focus solely on core property types or solely on specialty property types, aside from Hotel and Health Care REITs which we exclude from the sample, we are able to obtain very good matches to the REITs' portfolios

\footnotetext{
${ }^{22}$ See Brueggeman and Fisher (2008), for a textbook treatment.

${ }^{23}$ The reason we do not use the Korpacz IRRs for the study is due to the limited geographic dispersion available in these data.
} 
with just these four property types. Second, the reported cap rate has to be greater that $1 \%{ }^{24}$ Third, the price of the property has to be greater than $\$ 1$ million. ${ }^{25}$ Finally, the transaction cannot be a distressed sale.

Table 2 reports the descriptive statistics for the cap rate data by year and property type. Overall there were 101,594 property transactions in the sample. 11,752 of these were Industrial, 46,218 were Multifamily, 17,398 were Office and 26,226 were Retail. On average, Industrial properties experienced the highest average cap rate at $8.92 \%$, then Office at $8.80 \%$, then Retail at $8.70 \%$ and finally Multifamily at $7.76 \%$. The minimum and maximum cap rates show that there is a large degree of dispersion in property cap rates both by time and location. This dispersion in cap rates suggests that any property investor investing in different property types and locations will face differing investment opportunity sets.

In order to create an accurate investment opportunity set we exploit the portfolio characteristics of the REIT industry. If REITs held properties of all different property types in all locations, then they would all face the same investment opportunity set. Fortunately for our study, REITs tend to be focused by property type or location or both. ${ }^{26}$ This makes sense given the potential informational advantages of specializing by property type, location or both. The focused nature of REITs also provides a logical way of describing a REIT's investment opportunity set. When considering a new marginal project, a REIT is likely to consider a property in a market and property type in which it already operates. In this sense the current geographic and property type profile of the REIT provides a logical filter with which to select projects that the REIT might undertake. Thus by examining a REIT's

\footnotetext{
${ }^{24}$ Less than $1 \%$ of the cap rates in the sample are less than $3 \%$. Our results are not sensitive to using this cutoff.

${ }^{25}$ The average property in the sample has a price of $\$ 10.3$ million with the Office having the largest average price of $\$ 22.7$ million, then Retail with an average of $\$ 8.1$ million, then Multifamily with an average of $\$ 7.7$ million and finally Industrial with an average of $\$ 7.06$ million. smallest properties in the sample are $\$ 1$ million in value the largest is $\$ 5.4$ billion.

${ }^{26}$ For example, Washington REIT invests in multiple property types, but all within driving distance of Washington, DC. Simon Property Group invests only in retail properties, but invests across the US. Nearly all of SL Green's portfolio consists of Office properties in Manhattan.
} 
portfolio at a point in time and matching this to transactional cap rates observed in those markets, we can measure the investment opportunities that the REIT faces at a given point in time.

Calculating a REIT's investment opportunity set is a three step process. First, for each Core Based Statistical Area (CBSA), State, NCREIF region and then Nationally, we calculate the average transactional cap rate for four different property types Office, Industrial, Multifamily and Retail. ${ }^{27}$ Thus for each year, we have a measure of what cap rate an investor would face in each property type in each given geographic region. Second, for each REIT we build a geographic profile of the REIT's portfolio for each year. We obtain the REIT's property portfolio information from SNL, which provides details of property type and location. Finally, for each year we then match the REIT's property portfolio by property type with the transactional cap rate from Step 1, first at the CBSA level, then the State level, then at the NCREIF region level and finally at the National level until all properties are matched. Of the 217,579 property/years in the REITs' portfolios, 166,366 (76\%) were matched at the CBSA level, 28,575 (13\%) were matched at the State level, 20,664 (9\%) were matched at the NCREIF region level and 1,974 (2\%) were matched at the National level. ${ }^{28}$

Having matched each REIT property to a transactional cap rate in each year, we calculate Average Cap Rate, which is the average of these cap rates across the REIT's portfolio each year. This provides a measure of the average return on assets that a REIT would face on a typical project in its portfolio. Since repurchase decisions are likely to be made throughout the year, in our empirical specification for repurchases made in year $t$, we use the average

\footnotetext{
${ }^{27}$ NCREIF divides the US into 8 regions: North-East (ME, VT, NH, NY, CT, RI, MA, PA, NJ), Mid-East (MD, WV, VA, KY, NC, SC, DC, DE), South-East (TN, GA, FL, AL, MS), East North Central (MI, IL, OH, IN, WI), West North Central (MN, IA, MO, KS, SD, ND, NE), South West (TX, OK AR, LA), Mountain (ID, WY, UT, CO, NM, AZ) and Pacific (WA, OR, CA, AK, HI).

${ }^{28}$ The data from CoStar and Real Capital Analytics are heavily biased towards larger metro areas, so it is unlikely they are representative of cap rates in all US locations. Fortunately REIT portfolios are biased in the same manner, with REITs mainly investing larger metro areas, which is why we are able to match the majority of the sample at the CBSA level.
} 
cap rate from year $t-1$. As a robustness check, we calculate Average Cap Rate - BBB, the spread between the average cap rate and the BBB yield. This variable is quite commonly used in REIT analysis to gauge investment opportunities. The intuition behind it is quite simple. Most REITs trade at BBB credit ratings, so the BBB yield is approximately equal to the REIT's cost of debt. Since cap rates are the cash yield for the property, the spread between the average cap rate and the BBB yield measures the degree to which the property can cover its cost of debt. Obviously when Average Cap Rate - BBB is close to zero or negative, the property isn't generating sufficient cash flow to cover any debt, indicating a poor investment climate.

Table 3 reports descriptive statistics of Average Cap Rate and Average Cap Rate - BBB for the 125 REITs in our sample between 1996 and 2008. The most noticeable result from Table 3 is that there is both cross-sectional and time series variation in the investment opportunity set that REITs face. This indicates that the variation observed in transactional cap rates in Table 2 has not been averaged out by the composition of the REITs' portfolios. It also shows that REITs are not all facing the same investment opportunity set, which is critical for our study. On average there is a 347 b.p. difference between the cap rate faced by the REITs with the best and worst investment opportunity sets.

The overall pattern of cap rates reported in Table 3 is quite interesting. The marked decline in cap rates after 2001 coincides with a large influx of capital into commercial real estate. While this resulted in an overall decline in the level of cap rates, the spread between the average cap rate and the BBB yield indicates that the average cost of debt for REITs was also declining at the same time. Most noticeably this spread is quite low and even negative in the latter part of the sample, which is consistent with the anecdotal evidence that commercial real estate was over priced in the latter part of the sample period. 


\subsection{Other Characteristics}

In our empirical design we control for other potential explanations of repurchase behavior posited in the prior literature. In particular we control for stock options, agency cost explanations of repurchases, leverage, undervaluation, external financing costs.

\subsubsection{Stock Options}

Executive compensation is a factor potentially affecting repurchase behavior. ${ }^{29}$ Managers' incentives can be aligned with shareholders' interests by awarding managers stock options. Fenn and Liang (2001) argue that because of aligned incentives, managers would be more likely to pay out free cash flow to investors rather than invest in bad projects. Thus we would expect a positive relationship between stock options and repurchases.

Another channel through which stock options could affect repurchases is by making repurchases preferred to dividends as a mechanism to return capital to investors. Lambert, Lanen, and Larker (1989) argue that since executive stock options (like all call options) are negatively impacted by dividends, if managers wish to maintain the same overall payout ratio they would prefer repurchases to dividends. Once again we would expect a positive relationship between the level of option compensation and repurchase activity.

Options data are obtained from two sources. First, where available we obtain both unexercisable and unexercised but exercisable options from EXECUCOMP. EXECUCOMP's coverage of the REIT universe is quite limited, so where data are missing we hand collect the options data from the firm's proxy statements. Following Kahle (2002), we create two variables: Unexercisable Options, which is equal to outstanding unexercisable unexercised options divided by total shares outstanding, and Exercisable Options, which is equal to unexercised exercisable options divided by total shares outstanding.

\footnotetext{
${ }^{29}$ See Kahle (2002) for a detailed discussion.
} 


\subsubsection{Agency Costs}

Under agency cost explanations of repurchases, we would expect to observe firms with high levels of free cash flow repurchasing stock. By repurchasing stock the firm reduces Jensen (1986) style free cash flow agency problems. We employ two variables to proxy for free cash flow. First, Free Cash Flow is the firm's funds from operations divided by total assets. We use funds from operations because it is the standard measure of cash flow in the REIT industry. ${ }^{30}$ The second variable, also employed by Dittmar (2000) is Free Cash, which is the REIT's cash and marketable securities divided by total assets. ${ }^{31}$ In both cases we would expect to observe a positive relationship with repurchases.

\subsubsection{Leverage}

Firm leverage may also affect repurchase decisions. Since repurchasing stock will increase leverage, firms with high leverage are less likely repurchase stock since higher leverage will potentially increase expected bankruptcy costs. Leverage may also affect repurchase decisions because it reduces free cash flows. ${ }^{32}$ Leverage could also increase the volatility of the firm's free cash flow making it less likely to make repurchases because of a precautionary savings motive. In each case, we expected a negative relationship between share repurchases and leverage. We calculate the firm's leverage as total debt plus preferred stock divided by total capital (market value of equity plus the book value of debt and the book value of preferred stock.) Leverage is equal to the firm's leverage minus the average leverage in the industry during the year.

\footnotetext{
${ }^{30} \mathrm{FFO}$ is essentially equal to a REIT's net income, excluding gains or losses from sales of property, and adding back real estate depreciation.

${ }^{31}$ Results are similar if we use cash and marketable securities plus unused credit lines divided by total assets.

${ }^{32}$ See Jensen (1986).
} 


\subsubsection{Undervaluation}

Managers may choose to repurchase stock when the firm is undervalued. This is in fact a common explanation of the market's reaction to share repurchase announcements. To capture any potential undervaluation, we include the market to book ratio in our empirical specification. Market to Book is calculated as the firm's book value of assets minus book value of equity plus market value of equity all divided by book value of assets.

\subsubsection{External Funding Costs}

Firms that face lower external funding costs are likely to be less constrained in their ability to repurchase stock since future funding short falls can be raised at low cost in the future. We proxy external funding costs using Total Assets, the log of the firm's total assets. As argued by Smith and Watts (1992) and Opler and Titman (1993) larger firms are likely to have more stable cash flows and lower asymmetric information. The latter is also likely to be true for REITs, since as Boudry, Kallberg, and Liu (2009) show, firm size is a key determinant of analyst coverage.

\subsection{Descriptive Statistics}

Table 4 reports descriptive statistics for the independent variables in the analysis. The sample is bifurcated into repurchasing and non-repurchasing firms and a $t$ test of the difference in means between repurchasing and non-repurchasing firms is reported in the right most column. Consistent with the notion that poor investment opportunities lead to higher repurchases, we observe that the average cap rate and the spread between the average cap rate and $\mathrm{BBB}$ yield is higher for non-repurchasing than repurchasing firms. So at least in a univariate analysis their appears to be some support for this hypothesis.

While the average value of Exercisable Options and Unexercisable Options is larger for 
repurchasing than non-repurchasing firms, the difference is not statistically significant. The average values of $1.63 \%$ and $1.02 \%$ for non-repurchasing and $1.66 \%$ and $1.17 \%$ for repurchasing firms are similar to the averages reported in Ghosh, Harding, Sezer, and Sirmans (2008)

A relationship that runs counter to expectations are the variables related to agency costs. The average values of Free Cash Flow and Free Cash are higher for non-repurchasing firms especially for Free Cash. If firms with higher free cash flow pay out this cash flow to investors in the form of repurchases in order to avoid agency costs, we would expect to see a positive relationship with repurchases.

The average market to book ratio for non-repurchasing firms is 1.32 and the average for repurchasing firms in 1.21. This difference is highly statistically significant and if one assumes firms with lower market to book ratios are more likely to be undervalued, then the relationship is consistent with the undervaluation hypothesis.

Finally, repurchasing firms are larger than non-repurchasing firms. This is consistent with larger firms facing lower external financing costs and as such being less constrained in their ability to repurchase stock.

Table 5 reports a correlation matrix of the independent variables. As expected, Free Cash Flow has a strong negative correlation with Leverage of -0.53 . This is consistent with leverage being a mechanism to reduce free cash flow. Interestingly, Average Cap Rate and Market to Book have a negative correlation of -0.34 . This can be explained by the fact that when cap rates are low, property prices are high which should be reflected in the market value of the firm. It also suggests that they are capturing different effects. 


\section{Estimation Results}

We examine the relationship between investment opportunities and share repurchases in two ways. First, we treat share repurchases as a binary outcome and estimate the relationship between repurchasing shares and the independent variables in a Logit framework. Second, we treat share repurchases as a censored variable and estimate a Tobit model of share repurchases on the independent variables.

Table 6 reports estimation results for the random effects Logit model. The dependent variable takes the value of 1 if Repurchases is greater than zero and 0 otherwise. To aid interpretation, we report the change in the probability of repurchasing shares for a one standard deviation increase in the independent variables. Marginal effects are reported in percentages.

The marginal effects in Table 6 support the hypothesis that poor investment opportunities lead to more repurchases. Measuring the investment opportunity set using Average Cap Rate, we observe that a firm is $6.32 \%$ less likely to repurchase stock if the average cap rate faced by the firm increases by one standard deviation, or 132 b.p. Turning to Average Cap Rate - BBB we observe similar support. A one standard deviation increase in the spread between the average cap rate and the BBB yields makes a firm $8.26 \%$ less likely to repurchase stock. The strong statistical significance of these marginal effects demonstrates that a firm's investment opportunity does indeed play a role in the firm's choice to repurchase shares.

Consistent with the prior literature, we find that the market to book ratio has a strong negative relationship with share repurchases. A one standard deviation increase in the market to book ratio makes the firm approximately $14 \%$ less likely to repurchase stock. Interpreting high market to book ratios as a sign of possible overvaluation, this result is consistent with the undervaluation hypothesis.

External funding costs also appear to play a role in the firm's decision to repurchase stock. 
Consistent with larger firms being less constrained in their ability raise future funding, larger firms are significantly more likely to repurchase stock. A one standard deviation increase in total assets makes the firm approximately $14 \%$ more likely to repurchase stock. The magnitude of this marginal effect is not surprising given that REITs are a capital constrained sample of firms. As such it is natural to expect that the ability to raise future capital is a key determinant of the decision to repurchase stock today. Note that our measures of option compensation are never significant, which does not confirm the findings of Ghosh, Harding, Sezer, and Sirmans (2008).

Table 7 reports estimation results for a random effects Tobit model of Repurchases on the independent variables. Once again, to aid interpretation we report the marginal effects as the change in the dependent variable for a one standard deviation increase in the independent variable. Like in the Logit estimation in Table 6 , there is a statistically significant marginal effect for Average Cap Rate and Average Cap Rate-BBB in Table 7. A one standard deviation increase in the average cap rate faced by the REIT leads to a 21 b.p. decrease in repurchases. In terms of the spread between average cap rates and the BBB yield, a one standard deviation decrease in the spread leads to a 26 b.p. increase in repurchases. Given that the average level of repurchases in the sample is 90 b.p. this is quite a large effect.

Once again we also find that undervaluation and external financing costs have a significant impact on share repurchases. A one standard deviation increase in the market to book ratio leads to approximately a 60 b.p. decrease in repurchases, while a one standard deviation increase in total assets leads to approximately a 40 b.p. increase in repurchases. Unlike in the Logit estimation, stock options also appear to impact the magnitude of shares repurchased with Unexercised Options having a statistically significant marginal effect. Interestingly, in neither estimation does Free Cash Flow or Free Cash appear to be statistically significant. This may be due to high payout requirements effectively diminishing the magnitude of this repurchases channel compared to regular corporations. 


\section{Conclusion}

Previous studies on buyback behavior have demonstrated three general points. (i) Overvaluation plays a significant role in the repurchase decision: firms tend to buy back shares when they believe the shares are undervalued. (ii) Increases in option compensation tend to lead to more repurchase activity. (iii) Using market-to-book to proxy for investment opportunities, there is indirect evidence that the firm's opportunity set can influence the share repurchase decision.

This study, while offering evidence on each of these three issues, is novel in its much more direct investigation of point (iii). Using data on cap rates (a REIT's projected return on assets for a given property) we are able to construct a series of potential project returns for the 125 REITs in our sample; i.e., an approximation to the REIT's opportunity set at a given point in time. Thereby we address more precisely the over-investment hypothesis, firms repurchasing shares in lieu of investing in negative NPV projects, by linking these investment returns (as well as these returns in excess of a REIT's cost of borrowing) with buyback activity over time.

We find significant evidence for the over-investment hypothesis: REITs increase their repurchase activity significantly when cap rates are low and decrease it significantly when cap rates are high. This is noteworthy since our sample of REITs (because of institutional constraints on dividend payout) have far less divertible cash flow than industrial firms. Thus we would expect these results to be even stronger for non-REITs. We are also able to distinguish this effect from the over-valuation effect. We provide support for this hypothesis by using market-to-book in our Logit and Tobit analysis and estimating the correct negative impact on buyback activity: high market to book REITs are less likely to repurchase shares.

With regard to finding (ii), we find no support for the hypothesis that option compensation is a significant influence on REIT buyback activity. This result may be due to the 
fact that the average level of repurchases in our sample is lower than corresponding levels for industrial firms. 


\section{References}

Allen, Franklin, and Roni Michaely, 2002, Market timing and capital structure, Journal of Finance 62, 1-32.

Bagwell, Laurie, 1991, Share repurchase and takeover deterrence, Rand Journal of Economics $22,72-88$.

and John B. Shoven, 1989, Cash distributions to shareholders, Journal of Economic Perspectives 3, 129-140.

Baker, H., P. Gallagher, and K. Morgan, 1981, Managements' view of share repurchase programs, Journal of Financial Research pp. 233-247.

Banyi, Monica, Edward Dyl, and Kathleen Kahle, 2009, Errors in estimating share repurchases, Jounral of Corporate Finance p. Forthcoming.

Bartov, Eli, 1991, Open-market stock repurchase as signals for earnings and risk change, Journal of Accounting and Economics 14, 275-294.

Bens, Daniel, Venky Nagar, Douglas Skinner, and M.H. Franco Wong, 2003, Employee stock options, EPS dilution, and stock repurchases, Journal of Accounting and Economics 36, 51-90.

Bhattacharya, Sudipto, 1979, Imperfect information, dividend policy, and 'the bird in the hand' fallacy, Bell Journal of Economics 10, 259-270.

Bierman, Harold, and Richard West, 1966, The acquisition of common stock by the corporate issuer, Journal of Finance 4, 687-696.

Boudry, Walter I., 2009, An analysis of REIT dividend payout policy, Working Paper, Stern School of Business, NYU.

— Jarl G. Kallberg, and Crocker H. Liu, 2009, Analyst behavior and underwriter choice, Working Paper, Stern School of Business, NYU.

Brau, James C., and Andrew Holmes, 2006, Why do REITs repurchase stock? extricating the effect of managerial signaling in open market share repurchase announcements, Journal of Real Estate Research 28, 1-23.

Brav, Alon, John R. Graham, Campbell R. Harvey, and Roni Michaely, 2005, Payout policy in the 21st century, Journal of Financial Economics 77, 483-527.

Brockman, Paul, and Dennis Y. Chung, 2001, Managerial timing and corporate liquidity: Evidence from actual share repurchases, Journal of Financial Economics 61, 417-448.

Brueggeman, Willian B., and Jeffrey D. Fisher, 2008, Real estate finance and investments (McGraw-Hill: New York). 
Dann, Larry, 1981, Common stock repurchase: Analysis of returns to bond-holders and shareholders, Journal of Financial Economics 9, 113-138.

Dittmar, Amy, 2000, Why do firms repurchase stock?, Journal of Business 73, 331-355.

Elton, Edwin, and Martin Gruber, 1967, The effect of share repurchase on the value of the firm, Journal of Finance 23, 135-149.

Fenn, George, and Nellie Liang, 2001, Corporate payout policy and managerial stock incentives, Journal of Financial Economics 60, 45-72.

Gaver, Jennifer J., and Kenneth M. Gaver, 1993, Additional evidence on the association between the investment opportunity set and corporate financing, dividend and compensation policies, Journal of Accounting and Economics 16, 125-160.

Ghosh, Chimnoy, John Harding, Ozcan Sezer, and C.F. Sirmans, 2008, The role of executive stock options in REIT repurchases, Journal of Real Estate Research 30, 27-44.

Grullon, Gustavo, and Roni Michaely, 2002, Dividends, share repurchases and the substitution hypothesis, Journal of Finance 62, 1649-1684.

Guay, Wayne, and Jarrad Harford, 2000, The cash-flow permanence and information content of dividend increases versus repurchases, Journal of Financial Economics 57, 385-415.

Hardin, William, and Matthew Hill, 2008, REIT determinants: Excess dividends and capital markets, Real Estate Economics 36, 349-369.

Ikenberry, David, Josef Lakonishok, and Theo Vermaelen, 1995, Market underreaction to open market share repurchases, Journal of Financial Economics 39, 181-208.

, 2000, Share repurchases in Canada: Performance and strategic trading, Journal of Finance 55, 2373-2397.

Jagannathan, Murall, and Clifford Stephens, 2003, Motives for multiple open-market repurchase programs, Financial Management pp. 71-91.

- and Michael Weisbach, 2000, Financial flexibility and the choice between dividends and stock repurchases, Jounral of Financial Economics 57, 355-384.

Jensen, Michael, 1986, Agency costs of free cash flow, corporate finance, and takeovers, American Economic Review 76, 323-329.

Julio, Brandon, and David Ikenberry, 2004, Reappearing dividends, Journal of Applied Corporate Finance 16, 89-100.

Kahle, Kathleen M., 2002, When a buyback isn't a buyback: Open market repurchases and employee options, Journal of Financial Economics 63, 235-261. 
Kim, Jaemin, Ralf Schremper, and Nikhil Varaiya, 2005, Survey on open market repurchase regulations: Cross-country examination of the ten largest stock markets, Working Paper, San Diego State University.

Lambert, R.A., W.N. Lanen, and D.F. Larker, 1989, Executive stock option plans and corporate dividend policy, Journal of Financial and Quantitative Analysis 24, 409-425.

Lie, Erik, 2005, Operating performance following open market share repurchase announcements, Journal of Accounting and Economics 39, 411-436.

Miller, Merton, and Kevin Rock, 1985, Dividend policy under asymmetric information, Journal of Finance 40, 1031-1051.

Nohel, Tom, and Vefa Tarhan, 1998, Share repurchases and firm performance: New evidence on the agency cost of free cash flow, Journal of Financial Economics 49, 187-222.

Ofer, Aharon R., and Anjan V. Thakor, 1987, A theory of stock price responses to alternative corporate cash disbursement methods: Stock repurchases and dividends, Journal of Finance 42, 365-394.

Opler, T., and Sheridan Titman, 1993, The determinants of leveraged buyout activity: free cash flow vs. financial distress costs, Journal of Finance 48, 1985-1999.

Panovka, Robin, 2007, Robin panovka: REITs face a new reality, http://knowledge.wpcarey.asu.edu/article.cfm?articleid $=1560$.

Rau, P. Raghavendra, and Theo Vermaelen, 2002, Regulation, taxes and share repurchase in the u.k., Journal of Business 75, 245-282.

Smith, Clifford, and R.L. Watts, 1992, The investment opportunity set and corporate financing, dividends and compensation policies, Journal of Financial Economics 32, 263-292.

Vermaelen, Theo, 1981, Common stock repurchases and market signaling: An empirical study, Journal of Financial Economics 9, 138-183.

— , 1984, Repurchase tender offers, signaling and managerial incentives, Journal of Financial and Quantitative Analysis 19, 163-181.

Wansley, James, William Lane, and Salil Sarkar, 1989, Managements' view on share repurchase and tender offer premiums, Financial Management pp. 97-110.

www.v3.co.uk/vnunet/news/2210896/ibm-sets-aside-15bn-stock-repurchase. Feb.29. 2008. 


\section{Table 1: Repurchases}

Table reports descriptive statistics for share repurchases by the 125 REITs in the sample between 1996 and 2008. Repurchases is measured as the dollar value of common share repurchases during the year, divided by market capitalization at the start of the year. Where available, dollar value of common share repurchases is measured as common shares repurchased multiplied by average price of common shares repurchased reported in the company's financial statement. If these variables are not available, the dollar value of repurchases is measured as "Common Stock Repurchased" reported in the firm's statement of cash flows. Repurchases data were obtained from SNL. Shares outstanding is from CRSP. Repurchases are reported in percentages.

\begin{tabular}{cccccc}
\hline Year & Firms & Mean & Std & Min & Max \\
\hline 1996 & 76 & 0.1 & 0.46 & 0 & 2.48 \\
1997 & 79 & 0.05 & 0.26 & 0 & 1.7 \\
1998 & 95 & 0.62 & 2.05 & 0 & 13.36 \\
1999 & 97 & 2.14 & 4.72 & 0 & 33.9 \\
2000 & 93 & 2 & 3.35 & 0 & 17.83 \\
2001 & 92 & 1.5 & 3.71 & 0 & 20.41 \\
2002 & 90 & 0.82 & 2.27 & 0 & 18.53 \\
2003 & 90 & 0.73 & 3.06 & 0 & 26.5 \\
2004 & 92 & 0.33 & 1.28 & 0 & 8.92 \\
2005 & 84 & 0.64 & 1.85 & 0 & 8.65 \\
2006 & 76 & 0.69 & 1.86 & 0 & 11.27 \\
2007 & 74 & 1.25 & 2.55 & 0 & 16.24 \\
2008 & 74 & 0.52 & 1.84 & 0 & 14.27 \\
\hline Average & 86 & 0.88 & 2.25 & 0 & 14.93 \\
\hline
\end{tabular}




\section{Table 2: Capitalization Rates}

Table reports descriptive statistics of capitalization rates for 101,594 property transactions in the CoStar and Real Capital Analytics databases. Panel A reports statistics for Industrial and Multifamily properties while Panel B reports statistics for Office and Retail properties. Properties were excluded if the transaction cap rate was less than $1 \%$, the price was below $\$ 1$ million or the transaction was a distressed sale.

\begin{tabular}{|c|c|c|c|c|c|c|c|c|c|c|}
\hline \multicolumn{11}{|c|}{ Panel A: Industrial and Multifamily } \\
\hline & \multicolumn{5}{|c|}{ Industrial } & \multicolumn{5}{|c|}{ Multifamily } \\
\hline Year & Obs & Mean & Std & Min & Max & Obs & Mean & Std & Min & $\operatorname{Max}$ \\
\hline 1995 & 363 & 10.26 & 2.25 & 4.01 & 24.39 & 754 & 9.24 & 2 & 3.05 & 23.15 \\
\hline 1996 & 537 & 10.32 & 1.94 & 5.62 & 23.66 & 1099 & 9.47 & 2.11 & 2 & 19.44 \\
\hline 1997 & 527 & 10.05 & 1.69 & 4.52 & 23.06 & 1642 & 9.24 & 1.98 & 2 & 18.84 \\
\hline 1998 & 561 & 9.57 & 1.68 & 4.01 & 15.34 & 2002 & 8.83 & 1.93 & 2.83 & 17.78 \\
\hline 1999 & 740 & 9.66 & 1.82 & 4.22 & 20.87 & 2513 & 8.8 & 1.92 & 1.41 & 17.68 \\
\hline 2000 & 721 & 9.68 & 1.81 & 1.22 & 19.47 & 2823 & 8.6 & 1.98 & 1.12 & 17.82 \\
\hline 2001 & 767 & 9.59 & 1.6 & 3.03 & 18.03 & 3266 & 8.55 & 1.86 & 2.04 & 17.48 \\
\hline 2002 & 712 & 9.24 & 1.56 & 1.29 & 15.04 & 4132 & 7.92 & 1.77 & 3.17 & 15.81 \\
\hline 2003 & 937 & 8.87 & 1.59 & 1.94 & 18 & 4634 & 7.21 & 1.78 & 1.5 & 18.3 \\
\hline 2004 & 1048 & 8.2 & 1.63 & 3.16 & 15 & 5738 & 6.53 & 1.79 & 2.08 & 16.96 \\
\hline 2005 & 1277 & 7.76 & 1.71 & 2 & 15.49 & 6052 & 5.98 & 1.8 & 1.18 & 23.24 \\
\hline 2006 & 1377 & 7.22 & 1.47 & 2 & 14.5 & 4952 & 5.99 & 1.74 & 1.2 & 23.97 \\
\hline 2007 & 1513 & 7.08 & 1.43 & 2.6 & 15 & 4559 & 6.04 & 1.64 & 1.62 & 22.37 \\
\hline 2008 & 672 & 7.34 & 1.53 & 2 & 12.27 & 2052 & 6.18 & 1.67 & 1.59 & 15 \\
\hline \multicolumn{11}{|c|}{ Panel B: Office and Retail } \\
\hline & \multicolumn{5}{|c|}{ Office } & \multicolumn{5}{|c|}{ Retail } \\
\hline Year & Obs & Mean & Std & Min & Max & Obs & Mean & Std & Min & Max \\
\hline 1995 & 294 & 10.38 & 2.3 & 4.18 & 19.12 & 321 & 10.26 & 2 & 4.85 & 23.31 \\
\hline 1996 & 494 & 10.34 & 2.26 & 3.86 & 26.01 & 500 & 10.47 & 2.22 & 3.62 & 20.83 \\
\hline 1997 & 699 & 9.65 & 1.82 & 3.73 & 16.78 & 762 & 10.14 & 1.77 & 3.34 & 18.74 \\
\hline 1998 & 819 & 9.42 & 1.8 & 3.2 & 16.48 & 876 & 9.65 & 1.7 & 4.06 & 18.06 \\
\hline 1999 & 1074 & 9.77 & 1.78 & 3.49 & 23.37 & 1007 & 9.67 & 1.75 & 3 & 17.69 \\
\hline 2000 & 1166 & 9.67 & 1.65 & 2.48 & 15.71 & 1120 & 9.47 & 1.7 & 3.51 & 18 \\
\hline 2001 & 1170 & 9.65 & 1.72 & 2.31 & 20.89 & 1367 & 9.39 & 1.61 & 2.05 & 17 \\
\hline 2002 & 1308 & 9.28 & 1.66 & 1.84 & 25.11 & 1912 & 9.05 & 1.49 & 3.57 & 14.88 \\
\hline 2003 & 1441 & 8.82 & 1.56 & 2.62 & 14.82 & 2408 & 8.42 & 1.53 & 2.68 & 16 \\
\hline 2004 & 1827 & 8.1 & 1.66 & 2.2 & 16.14 & 2770 & 7.71 & 1.6 & 2.45 & 15 \\
\hline 2005 & 2004 & 7.42 & 1.6 & 1.3 & 14.98 & 3196 & 7.1 & 1.47 & 1.87 & 20.8 \\
\hline 2006 & 2015 & 7 & 1.45 & 2 & 14 & 3682 & 6.79 & 1.29 & 1.98 & 14.52 \\
\hline 2007 & 2183 & 6.7 & 1.44 & 2 & 13.2 & 4360 & 6.79 & 1.27 & 1.2 & 24.53 \\
\hline 2008 & 904 & 7.01 & 1.48 & 1.6 & 13.6 & 1945 & 6.94 & 1.27 & 1.58 & 13.96 \\
\hline
\end{tabular}


Table 3: Investment Opportunity Set

Table reports descriptive statistics of REIT portfolio cap rates for the 125 REITs in our sample between 1996 and 2008. For each year, the properties in the REIT's portfolio are matched by property type and location (CBSA, State, NCREIF region and Nationally) to transaction based cap rates from CoStar and Real Capital Analytics. Average Cap Rate is the average cap rate across the REIT's properties in a given year. Average Cap Rate - BBB is the spread between Average Cap Rate and the yield on BBB debt. Cap rates are reported in percentages.

\begin{tabular}{ccccccccccccc}
\hline & \multicolumn{1}{c}{ Average Cap Rate } & \multicolumn{4}{c}{ Average Cap Rate - BBB } \\
\hline Year & Firms & Mean & Std & Min & Max & Range & Mean & Std & Min & Max & Range \\
\hline 1996 & 76 & 10.44 & 0.6 & 8.78 & 12.31 & 3.53 & 2.39 & 0.60 & 0.73 & 4.26 & 3.53 \\
1997 & 79 & 10.43 & 0.6 & 8.6 & 11.74 & 3.15 & 2.56 & 0.60 & 0.73 & 3.87 & 3.15 \\
1998 & 95 & 9.99 & 0.45 & 8.14 & 10.91 & 2.77 & 2.77 & 0.45 & 0.92 & 3.69 & 2.77 \\
1999 & 97 & 9.9 & 0.56 & 8.17 & 12.22 & 4.05 & 2.02 & 0.56 & 0.29 & 4.34 & 4.05 \\
2000 & 93 & 9.91 & 0.39 & 8.04 & 10.73 & 2.69 & 1.54 & 0.39 & -0.33 & 2.36 & 2.69 \\
2001 & 92 & 9.8 & 0.53 & 7.77 & 10.94 & 3.17 & 1.85 & 0.53 & -0.18 & 2.99 & 3.17 \\
2002 & 90 & 9.62 & 0.5 & 7.87 & 10.9 & 3.03 & 1.82 & 0.50 & 0.07 & 3.10 & 3.03 \\
2003 & 90 & 9.24 & 0.58 & 7.25 & 11.59 & 4.34 & 2.48 & 0.58 & 0.49 & 4.83 & 4.34 \\
2004 & 92 & 8.64 & 0.61 & 6.49 & 10.43 & 3.93 & 2.25 & 0.61 & 0.10 & 4.04 & 3.93 \\
2005 & 84 & 7.99 & 0.61 & 5.78 & 9.78 & 3.99 & 1.93 & 0.61 & -0.28 & 3.72 & 3.99 \\
2006 & 76 & 7.46 & 0.65 & 5.34 & 9.02 & 3.68 & 0.98 & 0.65 & -1.14 & 2.54 & 3.68 \\
2007 & 74 & 6.98 & 0.61 & 5.14 & 8.36 & 3.22 & 0.50 & 0.61 & -1.34 & 1.88 & 3.22 \\
2008 & 74 & 6.76 & 0.62 & 5.12 & 8.74 & 3.61 & -0.68 & 0.62 & -2.32 & 1.30 & 3.61 \\
\hline Average & 86 & 9.01 & 0.56 & 7.12 & 10.59 & 3.47 & 1.72 & 0.56 & -0.17 & 3.30 & 3.47 \\
\hline
\end{tabular}




\section{Table 4: Descriptive Statistics}

Table reports descriptive statistics for the independent variables in the analysis. Data are for the 125 REITs in the sample between 1996 and 2008. Average Cap Rate is the REIT's average portfolio cap rate (in percentages), Average Cap Rate - BBB is the REIT's average portfolio cap rate minus the yield on BBB debt (in percentages). Exercisable Options is unexercised but exercisable options divided by shares outstanding (in percentages) and Unexercisable Options are unexercisable options divided by shares outstanding (in percentages). Free Cash Flow is funds from operations (FFO) divided by total assets (in percentages) and Free Cash is cash and marketable securities divided by total assets (in percentages). Leverage is the difference between the REIT's total debt plus preferred stock to total capital (in percentages) and the average Industry total debt plus preferred stock to total capital (in percentages). Market to Book is book assets minus book equity plus market value of equity all divided by total assets and Total Assets is the log of total book assets. Average Cap Rate and Average Cap Rate - BBB are calculated using data from CoStar and Real Capital Analytics, while all other data are from SNL except the options data which is from EXECUCOMP or the firm's proxy statements.

\begin{tabular}{lccccccccccc}
\hline & \multicolumn{4}{c}{ No Repurchase } & \multicolumn{1}{c}{ Repurchase } \\
\hline Variable & Obs & Mean & Std & Min & Max & Obs & Mean & Std & Min & Max & t test \\
\hline Average Cap Rate & 751 & 9.15 & 1.30 & 5.34 & 12.31 & 361 & 8.93 & 1.37 & 5.12 & 11.43 & -2.54 \\
Average Cap Rate - BBB & 751 & 1.88 & 1.00 & -1.64 & 4.83 & 361 & 1.54 & 1.09 & -2.32 & 4.04 & -5.16 \\
Exercisable Options & 751 & 1.63 & 2.24 & 0 & 17.9 & 361 & 1.66 & 1.74 & 0 & 8.31 & 0.23 \\
Unexercisable Options & 751 & 1.02 & 1.5 & 0 & 21.75 & 361 & 1.17 & 1.47 & 0 & 11.21 & 1.55 \\
Free Cash Flow & 751 & 5.73 & 2.61 & -5.45 & 26.7 & 361 & 5.63 & 2.31 & -9.32 & 12.6 & -0.64 \\
Free Cash & 751 & 11.47 & 9.48 & 0.29 & 94.3 & 361 & 9.5 & 6.03 & 0.26 & 40.56 & -3.61 \\
Leverage & 751 & -0.57 & 14.41 & -46.31 & 40.5 & 361 & 0.04 & 14.04 & -43.43 & 42.21 & 0.66 \\
Market to Book & 751 & 1.32 & 0.33 & 0.67 & 2.96 & 361 & 1.21 & 0.24 & 0.47 & 2.22 & -6.08 \\
Total Assets & 751 & 13.78 & 1.35 & 8.26 & 17.18 & 361 & 14.36 & 1.13 & 10.78 & 17.07 & 7.06 \\
\hline
\end{tabular}




\section{Table 5: Correlation Matrix}

Table reports correlations between the independent variables in the analysis. Data are for the 125 REITs in the sample between 1996 and 2008 . Average Cap Rate is the REIT's average portfolio cap rate (in percentages), Average Cap Rate - BBB is the REIT's average portfolio cap rate minus the yield on BBB debt (in percentages). Exercisable Options is unexercised but exercisable options divided by shares outstanding (in percentages) and Unexercisable Options are unexercisable options divided by shares outstanding (in percentages). Free Cash Flow is funds from operations (FFO) divided by total assets (in percentages) and Free Cash is cash and marketable securities divided by total assets (in percentages). Leverage is the difference between the REIT's total debt plus preferred stock to total capital (in percentages) and the average Industry total debt plus preferred stock to total capital (in percentages). Market to Book is book assets minus book equity plus market value of equity all divided by total assets and Total Assets is the log of total book assets. Average Cap Rate and Average Cap Rate - BBB are calculated using data from CoStar and Real Capital Analytics, while all other data are from SNL except the options data which is from EXECUCOMP or the firm's proxy statements.

\begin{tabular}{|c|c|c|c|c|c|c|c|c|c|}
\hline & $\begin{array}{c}\text { Average } \\
\text { Cap Rate }\end{array}$ & $\begin{array}{c}\text { Avg Cap } \\
\text { Rate - BBB }\end{array}$ & $\begin{array}{c}\text { Exercisable } \\
\text { Options }\end{array}$ & $\begin{array}{c}\text { Unexercisable } \\
\text { Options }\end{array}$ & $\begin{array}{c}\text { Free Cash } \\
\text { Flow }\end{array}$ & $\begin{array}{l}\text { Free } \\
\text { Cash }\end{array}$ & Leverage & $\begin{array}{l}\text { Market to } \\
\text { Book }\end{array}$ & $\begin{array}{l}\text { Total } \\
\text { Assets }\end{array}$ \\
\hline Average Cap Rate & 1 & & & & & & & & \\
\hline Avg Cap Rate - BBB & 0.83 & 1 & & & & & & & \\
\hline Exercisable Options & 0.15 & 0.08 & 1 & & & & & & \\
\hline Unexercisable Options & 0.28 & 0.17 & 0.23 & 1 & & & & & \\
\hline Free Cash Flow & 0.16 & 0.1 & -0.1 & 0.02 & 1 & & & & \\
\hline Free Cash & -0.05 & -0.02 & 0 & -0.05 & 0.05 & 1 & & & \\
\hline Leverage & 0.07 & 0.08 & 0.16 & 0.07 & -0.53 & -0.3 & 1 & & \\
\hline Market to Book & -0.34 & -0.21 & -0.08 & -0.11 & 0.25 & 0.25 & -0.38 & 1 & \\
\hline Total Assets & -0.39 & -0.31 & -0.02 & -0.01 & 0.04 & -0.22 & -0.05 & 0.08 & 1 \\
\hline
\end{tabular}




\section{Table 6: Decision to Repurchase}

Table reports estimation results for a random-effect panel Logit model. The dependent variable is equal to one if the firm repurchased shares during the year and zero otherwise. Marginal effects are reported for a one standard deviation change in the independent variable and are reported in percentages. Data are for the 125 REITs in the sample between 1996 and 2008. Average Cap Rate is the REIT's average portfolio cap rate (in percentages), Average Cap Rate - $B B B$ is the REIT's average portfolio cap rate minus the yield on BBB debt (in percentages). Exercisable Options is unexercised but exercisable options divided by shares outstanding (in percentages) and Unexercisable Options are unexercisable options divided by shares outstanding (in percentages). Free Cash Flow is funds from operations (FFO) divided by total assets (in percentages) and Free Cash is cash and marketable securities divided by total assets (in percentages). Leverage is the difference between the REIT's total debt plus preferred stock to total capital (in percentages) and the average Industry total debt plus preferred stock to total capital (in percentages). Market to Book is book assets minus book equity plus market value of equity all divided by total assets and Total Assets is the $\log$ of total book assets. Average Cap Rate and Average Cap Rate - $B B B$ are calculated using data from CoStar and Real Capital Analytics, while all other data are from SNL except the options data which is from EXECUCOMP or the firm's proxy statements.

\begin{tabular}{lcccc}
\hline Variable & Marginal Effect & t-stat & Marginal Effect & t-stat \\
\hline Average Cap Rate & -6.32 & -2.72 & & \\
Average Cap Rate - BBB & & & -8.26 & -4.45 \\
Exercisable Options & 2.95 & 1.54 & 2.66 & 1.39 \\
Unexercisable Options & 2.9 & 1.64 & 2.45 & 1.43 \\
Free Cash Flow & 2.15 & 0.88 & 2.13 & 0.9 \\
Free Cash & -3.18 & -1.52 & -3.16 & -1.51 \\
Leverage & -3.21 & -1.23 & -2.42 & -0.93 \\
Market to Book & -14.64 & -5.22 & -13.19 & -5.27 \\
Total Assets & 14.8 & 4.86 & 14.40 & 5.1 \\
\hline Obs & 1112 & & 1112 & \\
$\rho$ & 0.33 & & 0.34 & \\
$\chi^{2}(\rho=0)$ & 82.69 & & 84.78 & \\
\hline
\end{tabular}




\section{Table 7: Amount of Repurchases}

Table reports estimation results for a random effects panel Tobit model. The dependent variable Repurchases, is equal to the dollar amount of common shares repurchased during the year divided by market capitalization at the start of the year multiplied by 100. To aid interpretation, marginal effects are reported for a one standard deviation change in the independent variable. Data are for the 125 REITs in the sample between 1996 and 2008. Average Cap Rate is the REIT's average portfolio cap rate (in percentages), Average Cap Rate - $B B B$ is the REIT's average portfolio cap rate minus the yield on BBB debt (in percentages). Exercisable Options is unexercised but exercisable options divided by shares outstanding (in percentages) and Unexercisable Options are unexercisable options divided by shares outstanding (in percentages). Free Cash Flow is funds from operations (FFO) divided by total assets (in percentages) and Free Cash is cash and marketable securities divided by total assets (in percentages). Leverage is the difference between the REIT's total debt plus preferred stock to total capital (in percentages) and the average Industry total debt plus preferred stock to total capital (in percentages). Market to Book is book assets minus book equity plus market value of equity all divided by total assets and Total Assets is the log of total book assets. Average Cap Rate and Average Cap Rate - BBB are calculated using data from CoStar and Real Capital Analytics, while all other data are from SNL except the options data which is from EXECUCOMP or the firm's proxy statements.

\begin{tabular}{lcccc}
\hline Variable & Marginal Effect & t-stat & Marginal Effect & t-stat \\
\hline Average Cap Rate & -0.21 & -2.66 & & \\
Average Cap Rate - BBB & & & -0.26 & -4.1 \\
Exercisable Options & 0.01 & 0.14 & 0.00 & 0.01 \\
Unexercisable Options & 0.12 & 2.09 & 0.11 & 1.96 \\
Free Cash Flow & 0.07 & 0.85 & 0.06 & 0.79 \\
Free Cash & -0.13 & -1.7 & -0.12 & -1.64 \\
Leverage & -0.09 & -1.03 & -0.07 & -0.82 \\
Market to Book & -0.64 & -7.03 & -0.60 & -7.27 \\
Total Assets & 0.41 & 4.88 & 0.39 & 5.04 \\
\hline Obs & 1112 & & 1112 & \\
Left Censored & 751 & & 751 & \\
$\rho$ & 0.11 & & 0.1 & \\
$\chi^{2}(\rho=0)$ & 33.68 & & 33.29 & \\
\hline
\end{tabular}

